\title{
Assessment of Supply Chain Management Practices in Live Animal Export: The Case of Gurage Zone, Ethiopia
}

\author{
Ayal Adamu (MBA) ${ }^{1} \quad$ Samuel Gemechu (MBA) ${ }^{2}$ \\ 1.Department of Management, Injibara University, Wolkite, Ethiopia \\ 2.Department of Management, Wolkite University, Wolkite, Ethiopia
}

\begin{abstract}
The main purpose of this study was to assess supply chain management in live animal export. In order to meet the objectives of the study, a descriptive survey design was employed. Both secondary and primary data sources were employed. Primary data sources include questionnaire, interview, and focus group discussion were used. The target population of the study is livestock producers in some selected Woredas, firm exporter and livestock traders in the two target towns were selected by purposively sampling method. From the total population of 1500 household livestock producers' and 50 employees of exporter firms, 315 household livestock producers and 44 employees of exporter firms were randomly selected for this study. Finally, the data collected from the respondents were analyzed quantitatively and qualitatively by using descriptive Statistical Analysis Such as frequencies, mean values, standard deviations and t-tests. The information obtained through document, openended questionnaires, focus group discussion and the interviews were qualitatively analyzed to supplement the quantitative data. The findings revealed that the livestock producers, traders and exporters were the main actors of the supply chain. These actors were did not establish strong and effective mutual relationships cooperation, integration and coordination rather they all operate their respective business independently and traditionally. The current live animal traders practice in Gurage Zone seems to be the traditional linking with the producers. All live animal supply chain participants were used traditional way of gathering marketing information like personal observation. Therefore, it is recommended that serious awareness creation, workshops on livestock production, marketing and export regulation, policies and strategies have to be conducted to the supply chain participants and stakeholders of the sector that aimed to create conducive conditions for export trade.
\end{abstract}

Keywords: supply chain management, live animal, export

DOI: $10.7176 /$ IEL/9-4-03

Publication date:May $31^{\text {st }} 2019$

\section{INTRODUCTION}

The best companies around the world are discovering a powerful new source of competitive advantage. It's called supply-chain management and it encompasses all of those integrated activities that bring product to market and create satisfied customers (Handfield, 1998). As a result, supply chain theory, and practice have developed to the extent that supply chains, rather than single companies, are now see as units of competition (Handfield, 2002). Nevertheless, Supply chain management is still not well understood conceptually, and nor are future trends (Slone, 2004). The increment in livestock products is evident as many research results have showed that in both developed and developing nations there is a focus to improve this sector in order to gain significant economic and social benefits. The livestock sector in Europe has major opportunities to contribute to a more sustainable, climatically suitable and the sector gives more space for competitive Europe and ensure responsible European animal production in a changing global world (EU, 2013).

Others further study indicate that, the international market for live animals and meat is becoming increasingly competitive, and relevant actors must adopt improved practices in production, handling, fattening, transportation, processing and packaging of products to maintain and increase market share, to meet market requirements and maximize the benefits from the growing meat and live animal export trade (Amha, et al, 2011). These Market opportunities are increasing at a rapid rate for livestock products, fuelled by rising incomes, globalization, urbanization, and particularly in the developing world. At the same time, these opportunities bring increased complexity in the supply channels in marketing, distributing, organizing and governing high-value products (Mclend and Sutherland, 2012). According to McDermott, et al (2014), these opportunities ask for the questions on the ability of smallholder producers to contribute to this complex process. The smallholder participation in emerging and growing livestock markets is very crucial to make the supply chain to be more cost effective. Due to the potential opportunities that livestock provides, it can be observed that major development efforts made on livestock sector in both developed and developing countries are increasing (Nauman, 2014).

Naturally endowed with different agro-ecological zones and suitable environmental conditions, Ethiopia is a home for many livestock species and suitable for livestock production. Ethiopia is believed to have the largest livestock population in Africa (CSA, 2013/14). Recently Ethiopia's livestock market structures and characteristics showed that, many of the livestock markets in the country are categorize into primary market, secondary markets and terminal market. Furthermore, the basis of this classification as they indicated is that, 
mainly number of animals that attended the market per market day and the number of market participants in the market. In terms of market participants, primary markets are those in which the main sellers are producers and the main buyers are local assemblers and secondary markets are those in which the main sellers are local assemblers and main buyers are big traders. In terminal market the main sellers are traders and main buyers are butcheries and restaurants (Getachew, et al, 2008).

Gurage Zone is one among naturally endowed agro-pastoral regions of the country in terms of livestock population availability. Moreover, the Zone has a comparative advantage with its proximity to the Addis Ababa for its livestock export markets than other regions similar sectors.

Therefore the study assesses the supply chain management practice in live animals export and their major opportunity and challenges in selected Woredas, export firms in Butajira and Wolkite towns.

\section{OBJECTIVE OF THE STUDY}

- To identify the current status of live animal export supply chain management practices of the zone.

- To scrutinize major opportunity and challenges in the live animal export supply chain management of the study area.

\section{METHODOLOGY OF STUDY}

Descriptive research designs have been used in this study. The target population of the study is livestock producers in some selected Woredas, firm exporter and livestock traders in the two target towns were selected by using purposive sampling method. According to Gurage office of Rural and Agricultural Development and its branch offices in (Meskan, Abeshge, Cheha, Enamor, and Esha) Woredas were indicated that, there are total 1500 household livestock producers who supply livestock in primary market, and 50 employees of export firms were currently worked in two town administration (35 employees are in Mohammed Nuri export firms at Butajira town and 15 employees are in Tofik Agizow export firms at Abeshege Woreda). Six individual traders were included as the interview response. Again the five branch Woredas of Rural and Agricultural sectors coordinator were included on the focus group discussion.

From the total population of 1500 household livestock producers' and 50 employees of exporter firms, 315 household livestock producers and 44 employees of exporter firms were randomly selected for this study. Finally, the data collected from the respondents were analyzed quantitatively and qualitatively by using descriptive Statistical analysis such as frequency, percentage, mean values, standard deviations and t-tests. The information obtained through document, open-ended questionnaires, focus group discussion and the interviews were qualitatively analyzed to supplement the quantitative data.

\section{DATA ANALYSIS AND DISCUSSION}

4.1. The Business Experience of Live Animal Producer

Table 1: Type of market in which live animal sold and level of producer's beneficiaries

\begin{tabular}{|l|l|l|l|}
\hline \multirow{3}{*}{ Items } & & $\mathrm{n}=265$ & \multicolumn{1}{l|}{} \\
\cline { 3 - 4 } & Variables & Frequency & $\%$ \\
\hline \multirow{3}{*}{ Previous business } & Agent & 18 & 6.8 \\
& Trader & 76 & 28.7 \\
& Broker & 32 & 12.1 \\
& Livestock Producer & 108 & 40.8 \\
& No response & 31 & 11.7 \\
& Total & 265 & 100.0 \\
\hline \multirow{3}{*}{ Have formal market } & Yes & 116 & 43.8 \\
& No & 149 & 56.2 \\
& Total & 265 & 100.0 \\
\hline & Primary market & 163 & 61.5 \\
& Secondary market & 59 & 22.3 \\
& Terminal market & 43 & 16.2 \\
& Total & 265 & 100.0 \\
\hline \multirow{3}{*}{ More beneficiaries } & Producers & 47 & 17.7 \\
& Local traders & 135 & 50.9 \\
& Agents & 12 & 4.5 \\
& Trading & 62 & 23.4 \\
& Export firms & 9 & 3.4 \\
& Total & 265 & 100.0 \\
\hline
\end{tabular}

(Source: survey, 2017) 
From Table 1 the above, the researchers can observe that out of the 265 live animal producers, $40.8 \%$ of them practices live animal producers in previous their life, $28.7 \%, 12.1 \%$ and $6.8 \%$ were practice in their previous life traders, brokers and an agent respectively. Regarding to item 2 from the same table, more than half of respondents said that there is no formal market for live animal product at live animal's producer's environment. Similarly, $61.5 \%$ of producer were sold their product at primary market, $22.3 \%$, and $16.2 \%$ were sold at secondary and tertiary market respectively. It's better to conclude that the majority of live animal producer were limited to within primary market. Regarding the level of beneficiary, $50.9 \%$ of the beneficiaries are local traders. $23.4 \%, 17.7 \%$ and $3.4 \%$ of beneficiaries are lager traders, producers, and export firms respectively. In the same way, data obtained from the interview made with local traders, and focus group discussion made with animal health bureau heads and their branch confirm that there is unsecured balances of benefits from live animal marketing practices.

4.2. Accessibility of Market Information in Live Animal producer Supply Chain Table 2: Live animal's market information availability

\begin{tabular}{|c|c|c|c|}
\hline \multirow[b]{2}{*}{ Items } & \multirow[b]{2}{*}{ Variables } & \multicolumn{2}{|l|}{$\mathrm{n}=265$} \\
\hline & & Frequency & $\%$ \\
\hline $\begin{array}{l}\text { have well organized source of } \\
\text { information's }\end{array}$ & $\begin{array}{l}\text { Yes } \\
\text { No } \\
\text { Total }\end{array}$ & $\begin{array}{l}116 \\
149 \\
265 \\
\end{array}$ & $\begin{array}{l}43.8 \\
56.2 \\
100.0\end{array}$ \\
\hline Center for market information & $\begin{array}{l}\text { Government agency } \\
\text { Non-governmental agency } \\
\text { Informal from local trader } \\
\text { No Response } \\
\text { Total }\end{array}$ & $\begin{array}{l}44 \\
32 \\
36 \\
153 \\
265 \\
\end{array}$ & $\begin{array}{l}16.6 \\
12.1 \\
13.6 \\
57.7 \\
100.0\end{array}$ \\
\hline $\begin{array}{l}\text { Sources of information on live } \\
\text { animals market price }\end{array}$ & $\begin{array}{l}\text { From Dagu } \\
\text { Personal observation } \\
\text { Other producer } \\
\text { Agents } \\
\text { Brokers } \\
\text { If other specify } \\
\text { Total }\end{array}$ & $\begin{array}{l}12 \\
24 \\
192 \\
20 \\
14 \\
3 \\
265\end{array}$ & $\begin{array}{l}4.5 \\
9.1 \\
72.5 \\
7.5 \\
5.3 \\
1.1 \\
100.0\end{array}$ \\
\hline level of satisfied with information & $\begin{array}{l}\text { Highly satisfied } \\
\text { Satisfied } \\
\text { Moderately satisfied } \\
\text { Unsatisfied }\end{array}$ & $\begin{array}{l}8 \\
30 \\
108 \\
119 \\
265\end{array}$ & $\begin{array}{l}3.0 \\
11.3 \\
40.8 \\
44.9 \\
100.0\end{array}$ \\
\hline Have a linkage with buyers & $\begin{array}{l}\text { Yes } \\
\text { No } \\
\text { No Response }\end{array}$ & $\begin{array}{l}128 \\
134 \\
3 \\
265\end{array}$ & $\begin{array}{l}48.3 \\
50.6 \\
1.1 \\
100.0\end{array}$ \\
\hline
\end{tabular}

(Source: survey, 2017)

Table 2 regarding the well-organized source of information in live animal marketing shows that $56.2 \%$ and $43.8 \%$ of the respondents were said that yes and no respectively. Regarding the center of marketing information, $57.7 \%$ of respondents were not giving response. $16.6 \%, 13.6 \%$ and $12.1 \%$ of respondents were said that government agency, informal local trader, and non-government agency respectively. Hence, this indicates that the majority of the respondents in the live animal's producer were not giving response showing that the unclear formal centers of marketing information for live animal's producer.

The above table 2 also shows that $44.9 \%$ of the respondents were unsatisfied with marketing information's. This indicates that there is no enough marketing information for live animal's producer. Regarding the live animals producer strong relation with buyers, $50.6 \%$ of the respondents have weak relationship. This shows that almost half of the respondents have not strong relation with live animal's product purchaser. In addition, data obtained from both the interview and focus group discussion revealed that there is poor supply chain management regarding the updating formal market information for live animal product. 


\subsection{Management and Marketing Practice in Live Animal Supply Chain}

Table 3: The Extent of Management and Marketing Practice in Live Animal Supply Chain

\begin{tabular}{|c|c|c|c|c|c|c|c|}
\hline \multirow[b]{3}{*}{ Items } & \multirow{3}{*}{ Mean } & \multirow{3}{*}{$\mathrm{SD}$} & \multicolumn{5}{|c|}{ Test Value $=3$} \\
\hline & & & \multirow[b]{2}{*}{ value } & \multirow[b]{2}{*}{$\begin{array}{l}\mathrm{p}- \\
\text { value }\end{array}$} & \multirow[b]{2}{*}{$\begin{array}{l}\text { Mean } \\
\text { Difference }\end{array}$} & \multicolumn{2}{|c|}{$\begin{array}{l}95 \% \text { Confidence } \\
\text { Interval }\end{array}$} \\
\hline & & & & & & Lower & Upper \\
\hline $\begin{array}{l}\text { Good management practice on Live } \\
\text { animal safety, health, weight, and age }\end{array}$ & 2.77 & 1.399 & -2.635 & .009 & -.226 & -.40 & -.06 \\
\hline $\begin{array}{l}\text { Strong mutual } \\
\text { livestock trading }\end{array}$ & 2.56 & 1.160 & -6.195 & .000 & -.442 & -.58 & -.30 \\
\hline Relations among supply chain actors & 3.04 & 1.376 & .447 & .656 & .038 & -.13 & .20 \\
\hline Certainty of market price of live animal & 2.89 & 1.238 & -1.489 & .138 & -.113 & -.26 & .04 \\
\hline Availability of update market information & 2.98 & 1.261 & -.292 & .770 & -.023 & -.18 & .13 \\
\hline Distance approach to market & 3.15 & 1.310 & 1.828 & .069 & .147 & -.01 & .31 \\
\hline $\begin{array}{l}\text { Clear government policy regarding live } \\
\text { animal market price. }\end{array}$ & 2.89 & 1.582 & -1.165 & .245 & -.113 & -.30 & .08 \\
\hline $\begin{array}{l}\text { Balance benefits for all supply chain } \\
\text { actors. }\end{array}$ & 2.65 & 1.425 & -3.966 & .000 & -.347 & -.52 & -.17 \\
\hline
\end{tabular}

(Source: survey, 2017); significant at $\alpha 0.05$ level, $t$-critical value (1.96) $d f=264$

It can be seen from table 3 Item 1; respondents were asked to give their levels agreement regarding good management practice in live animal safety, health weight, and age. The mean score of live animal's producers is 2.77. The t-test result with p-value of $0.009<0.05$ indicates that there is statistically significant difference from moderate level towards the item. This shows that the management practice in live animal safety, health weight, and age was below moderate level of agreement. Regarding item 2 and item 8 in the above table, the levels of mutual relationships with livestock trading, cooperative and exporters, and balance benefits for all supply chain actors was also rated by live animal producers of the respondents. The average agreement level of mean scores of the respondents was 2.56 and 2.65 respectively. The t-test result with p-value for both Items $0.000<0.05$ shows that there is statistically significant difference from moderate levels of agreement respondents towards the item.

4.4. Accessibility of Market Information in Live Animal Export Supply Chain Table 4: Source of information for live animal exports

\begin{tabular}{|c|c|c|c|c|}
\hline \multirow[t]{2}{*}{ Items } & \multirow[b]{2}{*}{ Variables } & \multicolumn{3}{|c|}{$\mathrm{n}=30$} \\
\hline & & No & $\%$ & Valid \% \\
\hline \multirow[t]{2}{*}{ Well-organized source of information } & No & 30 & 100.0 & 100.0 \\
\hline & Total & 30 & & \\
\hline $\begin{array}{l}\text { The way getting information on the price of } \\
\text { live animals }\end{array}$ & Personal observation & 30 & 100.0 & 100.0 \\
\hline \multirow{4}{*}{$\begin{array}{l}\text { The way getting information on the supply of } \\
\text { live animals }\end{array}$} & Personal observation & 23 & 76.7 & 76.7 \\
\hline & Agents & 3 & 10.0 & 10.0 \\
\hline & Brokers & 4 & 13.3 & 13.3 \\
\hline & Total & 30 & 100 & 100 \\
\hline \multirow{3}{*}{$\begin{array}{l}\text { The way to get information on the demand of } \\
\text { live animals }\end{array}$} & Contact office & 4 & 13.3 & 13.3 \\
\hline & Contact person & 26 & 86.7 & 86.7 \\
\hline & Total & 30 & 100 & 100 \\
\hline
\end{tabular}

(Source: survey, 2017)

Response results from Table 4 about the existence of well-organized markets information indicates, 100\% of respondents were replied that there is no well-organized source of market information concerned with live animal trading practice. Thus, exporters and employees of export firms had been used other means of access to markets livestock price and live animal supply information as responses indicates, $100 \%$ of respondents got information through personal observation. Similarly, the data obtained from Traders though the Interview reveals that the market information related to Livestock price was not centralized, and the livestock product supply to the market also seasonal. 
Table 5: level of management practices in live animal export supply chain

\begin{tabular}{|c|c|c|c|c|c|c|c|}
\hline \multirow[t]{2}{*}{ Items } & \multirow[t]{2}{*}{ Mean } & \multirow[t]{2}{*}{ SD } & \multirow[b]{2}{*}{$\mathrm{t}$-value } & \multirow{2}{*}{$\begin{array}{l}\text { p- } \\
\text { valu } \\
\text { e }\end{array}$} & \multirow{2}{*}{$\begin{array}{l}\text { Mea } \\
\text { n } \\
\text { Diffe } \\
\text { renc } \\
\text { e }\end{array}$} & \multicolumn{2}{|c|}{$\begin{array}{l}95 \% \\
\text { Confidenc } \\
\text { e Interval } \\
\end{array}$} \\
\hline & & & & & & $\begin{array}{l}\text { Low } \\
\text { er }\end{array}$ & $\begin{array}{l}\text { Up } \\
\text { per }\end{array}$ \\
\hline $\begin{array}{l}\text { There are good management practice on Live animal } \\
\text { safety, health, weight, and age in supplied to the export } \\
\text { markets }\end{array}$ & 2.87 & .629 & -1.161 & .255 & -.133 & -.37 & .10 \\
\hline $\begin{array}{l}\text { There are strong mutual relationships with livestock } \\
\text { trading cooperatives or producers. }\end{array}$ & 3.47 & .900 & 2.841 & .008 & .467 & .13 & .80 \\
\hline There are closed relations among supply chain actors. & 3.50 & .731 & 3.746 & .001 & .500 & .23 & .77 \\
\hline $\begin{array}{l}\text { There is a certainty of market price of live animal in } \\
\text { any time }\end{array}$ & 2.60 & .855 & -2.562 & .016 & -.400 & -.72 & -08 \\
\hline There is availability of update market information. & 1.87 & .973 & -6.378 & .000 & $\begin{array}{l}- \\
1.13 \\
3\end{array}$ & $-\overline{1}$ & -77 \\
\hline There are balance benefits for all supply chain actors. & 2.97 & .890 & -.205 & .839 & -.033 & -.37 & .30 \\
\hline
\end{tabular}

(Source: survey, 2017); significant at $\alpha 0.05$ level, t-critical value (1.96) $\mathrm{df}=29$

The export firms have an average agreement level of mean 2.87 regarding of the good management practice on live animal safety, health, weight, and age in supplied to the exporter markets. The t-test result with p-value of $0.255>0.05$ indicates that there is no significant difference from the moderate level of agreement.

Regarding strong relationship among supply chain actors by mean, the mean score of export firm's respondents were 3.47, and 3.50 respectively. The t-test result with p-value of 0.008 and $0.001<0.05$ respectively indicates that there is statistically significant difference from moderate level of agreement towards the two items. Similarly, 95\% Confidence Interval of the Difference mean of the two Items are $0.33-0.080$ and $0.23-0.77$ respectively indicates that there is no the chance of the mean of the two Items are zero value. This proves that the respondents of live animals export firms have the above moderate level of the agreement towards the Items.

The Item 4 and Item5 from the above table5 deals with the availability of live animals market information. The live animal's export firms have average agreement level of mean 2.60 and 1.87 respectively. The t-test result with p-value of 0.016 and $0.00<0.05$ respectively indicates that there is the statistically significant difference from moderate level of the agreement toward the Items. Similarly, 95\% Confidence Interval of the Difference mean of the two Items are -0.72 up to -0.08 and -1.50 up to -0.77 respectively indicates that there is no the chance of the mean of the two Items are zero value. This proves that the respondents of live animals export firms have below moderate level of the agreement towards the Items.

\subsection{Major Challenges in Live Animal Export Supply Chain}

Table 6: External factors affecting the performance of live animal's exporter firms

\begin{tabular}{|c|c|c|c|c|c|c|c|}
\hline \multirow{3}{*}{ Items } & \multicolumn{7}{|c|}{ Test Value $=3$} \\
\hline & \multirow[b]{2}{*}{ Mean } & \multirow{2}{*}{ SD } & \multirow[b]{2}{*}{ t-value } & \multirow[b]{2}{*}{$\begin{array}{c}\mathrm{p}- \\
\text { value }\end{array}$} & \multirow[t]{2}{*}{$\begin{array}{c}\text { Mean } \\
\text { Difference }\end{array}$} & \multicolumn{2}{|c|}{$\begin{array}{l}95 \% \text { Confidence } \\
\text { Interval }\end{array}$} \\
\hline & & & & & & Lower & Upper \\
\hline Shortage of financial access & 2.57 & .774 & -3.067 & .005 & -.433 & -.72 & -.14 \\
\hline Lack of business experience & 4.23 & .430 & 15.703 & .000 & 1.233 & 1.07 & 1.39 \\
\hline limited market information & 3.83 & .379 & 12.042 & .000 & .833 & .69 & .97 \\
\hline Legal and policy constraints & 3.03 & 1.326 & .138 & .891 & .033 & -.46 & .53 \\
\hline Available of infrastructures & 2.33 & .758 & -4.817 & .000 & -.667 & -.95 & -.38 \\
\hline Location of market & 2.57 & .774 & -3.067 & .005 & -.433 & -.72 & -.14 \\
\hline $\begin{array}{l}\text { Shortage of livestock during high } \\
\text { demand }\end{array}$ & 2.33 & .758 & -4.817 & .000 & -.667 & -.95 & -.38 \\
\hline Lack of technology & 3.93 & .640 & 7.992 & .000 & .933 & .69 & 1.17 \\
\hline Insecurity of the routes & 3.67 & .758 & 4.817 & .000 & .667 & .38 & .95 \\
\hline
\end{tabular}

(Source: survey, 2017); significant at $\alpha 0.05$ level, $\mathrm{t}$-critical value (1.96) $\mathrm{df}=29$ 
It can be seen from Table 6 Item 1, Item5, Item6, and Item7 that the live animal export firms have an average agreement level of mean $2.57,2.33,2.57$ and 2.33 respectively. The t-test result with the p-value of $0.005,0.000,0.005$ and 0.000 respectively less than 0.05 indicates that there is a significant difference from the moderate levels of the agreement. This implies that the live animal export firms have the below moderate levels of agreement regarding the external factors affecting the performance of live animal export firms.

From the above Table 6, Item4 that exporters have an average agreement level of mean 3.03. The t-test result with p-value of $0.891>0.05$ indicates that there is no significant difference from the moderate level of agreement. This means the live animal's export firms have the moderate level of agreement towards the legal, institutional and policy constraints related to the live animals trade.

Regarding the Item2, Item3, Item8, and Item9 from Table 6 the live animal export firms have an average agreement level of mean 4.23, 3.83, 3.93 and 3.67 respectively. The t-test result with p-value of the four Items is 0.000 less than 0.05 indicates that there is a significant difference level of agreement from the moderate level of agreement. Because of the $95 \%$ of the confidence interval of mean difference for the all Items located into the positive domain, the export firms have above moderate level of agreement for external factors. This revealed that unavailability of business trainings provided by concerned government agencies, limited market information, Lack of technology and Insecurity of the routes are the major external factors currently affecting the live animal export firms.

Table 7: Internal factors affecting the performance of live animals exporter firms

\begin{tabular}{|c|c|c|c|c|c|c|c|}
\hline \multirow[b]{3}{*}{ Items } & \multicolumn{7}{|c|}{ Test Value $=3$} \\
\hline & \multirow[t]{2}{*}{ Mean } & \multirow[t]{2}{*}{ SD } & \multirow[b]{2}{*}{ t-value } & \multirow{2}{*}{$\begin{array}{l}\text { p- } \\
\text { value }\end{array}$} & \multirow{2}{*}{$\begin{array}{l}\text { Mean } \\
\text { Difference }\end{array}$} & \multicolumn{2}{|c|}{$\begin{array}{l}95 \% \text { Confidence } \\
\text { Interval }\end{array}$} \\
\hline & & & & & & Lower & Upper \\
\hline Lack of managerial skills & 2.83 & .913 & -1.000 & .326 & -.167 & -.51 & .17 \\
\hline Quality Disputes & 4.23 & .430 & 15.703 & .000 & 1.233 & 1.07 & 1.39 \\
\hline Quantity Disputes & 3.73 & .868 & 4.626 & .000 & .733 & .41 & 1.06 \\
\hline Bureaucratic & 3.13 & .571 & 1.278 & .211 & .133 & -.08 & .35 \\
\hline Health and inspection problems & 2.97 & 1.245 & -.147 & .884 & -.033 & -.50 & .43 \\
\hline Location of firm & 2.57 & .774 & -3.067 & .005 & -.433 & -.72 & -.14 \\
\hline linkage with supply chain actors & 2.87 & 1.196 & -.611 & .546 & -.133 & -.58 & .31 \\
\hline Over extension of credit & 2.87 & 1.279 & -.571 & .573 & -.133 & -.61 & .34 \\
\hline Lack of Employees Satisfaction & 3.10 & .960 & .571 & .573 & .100 & -.26 & .46 \\
\hline
\end{tabular}

(Source: survey, 2017); significant at $\alpha 0.05$ level, t-critical value (1.96) $\mathrm{df}=29$

It can be seen from Table 7 item 6 that export firms have an average agreement level of mean 2.57 . The $\mathrm{t}$ test result with $\mathrm{p}$-value of $0.005<0.05$ shows that there is a significant difference from the moderate level of agreement. This indicates that exporters have below moderate level of agreement for Location of exporter firms which is one of the internal factors that is affecting the performance of live animal's export firms.

As it is indicated on Item 1, Item4, Item5, Item7, Item8 and Item9 in Table 7, the computed mean scores from respondents of live animals export firms were 2.83, 3.13, 2.97, 2.87, 2.87 and 3.10 respectively. The t-test result with p-value of $0.326,0.211,0.884,0.546,0.573$, and 0.573 respectively, greater than 0.05 indicates that the respondents do not significantly vary in their average agreement from the moderate level of agreement towards the items. These shows that exporters have moderate level of agreement for the elements of internal factors such as lack of managerial skills, over extension of credit, lack of employees satisfaction and bureaucratic across the firms that is affecting the performance of live animals export firms.

Regarding the Item 2 and Item 3 in Table 7, the computed mean scores from respondents of live animals export firms were 4.23 and 3.73 respectively. The t-test result with p-value of the two Items 0.000 less than 0.05 indicates that there is a significant difference level from the moderate level of the agreements. Due to the $95 \%$ of confidence interval of mean difference were located with the positive domain of the interval shows that there is no the probability of zero value of mean items realizing that the exporters have the above moderate level of agreement. 


\subsection{Major Challenges in Live Animal producer Supply Chain}

Table 8: challenges of live animal producer in exports of supply chain

\begin{tabular}{|l|l|l|l|}
\hline & Number of YES & n $=265$ & Rank \\
\cline { 3 - 4 } & responses & \%age & 3 \\
\hline Price dispute & 176 & 66.4 & 3 \\
\hline Quality dispute & 175 & 66.0 & 4 \\
\hline Quantity dispute & 110 & 41.5 & 16 \\
\hline Health and inspection problem & 169 & 63.8 & 6 \\
\hline Location of market & 180 & 67.9 & 1 \\
\hline Shortage of live stock & 170 & 64.2 & 5 \\
\hline Skill/knowledge of producer & 122 & 46.0 & 13 \\
\hline Government policy & 121 & 45.7 & 12 \\
\hline Transportation & 163 & 61.5 & 7 \\
\hline Lack of supporting technology & 118 & 44.5 & 11 \\
\hline Competitors & 125 & 47.2 & 15 \\
\hline Disease & 117 & 44.2 & 9 \\
\hline Illegal traders & 162 & 61.1 & 8 \\
\hline Routes insecurity & 142 & 46.4 & 14 \\
\hline Local tax & 117 & 44.2 & 9 \\
\hline Unsatisfactory marketing system & 178 & 67.2 & 2 \\
\hline
\end{tabular}

(Source: survey, 2017)

As shown in Table 8 above, six high factors such as quantity dispute, competition from illegal traders, insecurity of trade channel in supply chain, skill and knowledge of producers, government policy, lack of supporting technology, local tax and disease were 58.5\%,52.8\%, 53.6\%, 54\%, 54.3\%,55.5\%, 55.8\%, and 55.8\% yes scored respectively. This show that live animals producers were more challenging with quantity dispute, competition from illegal traders, insecurity of supply chain, skill and knowledge of producers, government policy, lack of supporting technology, local tax and disease in the export supply chain.

Further, as expert key informants focus group discussion at both zonal and district levels indicated that the major challenges for controlling the live animal export in Gurage Zone are competition from illegal traders, insecurity of trade channel in supply chain, skill and knowledge of producers, weak government policy, lack of supporting technology and disease.

\section{CONCLUSION AND RECOMMENDATION}

Live animal producers and lives animals' export firms were limited to within primary market structure only. The alternative market opportunities available for live animal trade were not advanced.

The benefits obtained by the live animal producer and live animal export firms from live animal trade in Gurage were not equivalent with local traders and larger traders. There were unbalanced benefits among live animal supply chain participants. This indicates that animal health bureau heads and Woreda branches were not secured the balance benefits from live animal trade.

In live animal trade, live animal producer and live animals export firms were not got update marketing information's. Currently, marketing information's was obtained through personal observation. This indicates that live animal producers and export firms were used traditional ways of gathering marketing information as well as undeveloped marketing system. The distribution channels for live animal export system were less safety, poor infrastructure as physical network of plants and distribution be structured, informal third-party logistics capabilities, unfixed transportation services can best link together the network of facilities which are affects costservice performance and establishes the boundaries within which the supply chain must operate which is meet business goal and customer needs.

Animal health bureau heads and Woreda branches were not established the core supply chain processing activities like manufacturing, integrated demand planning, procurement, cycle-time compression, linkages with their suppliers and customers, dynamic deployments which are driving the business activity. The formal live animal supply chain was not organized which is the success factors of cohesion, harmony, and integration across their business entities. This shows that supply chain management practice in live animal export were not effective and efficient.

The major challenges in live animals producers were quantity dispute, competition from illegal traders, and insecurity of trade channel in supply chain, skill and knowledge of producers, standard government policy, and lack of supporting technology, local tax and disease in the export supply chain. This indicates that live animals producers were challenged by a numbers of factors.

The major challenges in the live animal export supply chain among external factors were Lack of business 
experience, limited market information, Lack of technology and Insecurity of the routes affecting the performances of live animal's exporter firms. Quality disputes and quantity disputes were the two major internal factors challenging the live animals export supply chain. This revealed that unavailability of business trainings provided by concerned government agencies, limited market information, Lack of technology and Insecurity of the routes, quality disputes and quantity disputes were the major external and internal factors currently affecting the activity of live animal export firms.

Based on the finding, the following recommendations have been given:

$>$ The study revealed the benefits obtained by live animal supply chain participants from live animal trade were not balanced. Thus, concerned government bodies (animal health bureau heads and Woreda branches) should secured the balance of benefit among the live animal supply chain participants such as producer, traders, and export firms to keep the real business practices.

$>$ The study shows that the core supply chain processing activities like manufacturing, integrated demand planning, procurement, cycle-time compression, linkages with their suppliers and customers, dynamic deployments which are driving the business activity were not established. Animal health bureau heads and wareda concerned government bodies should have to establish effective marketing linkages between producers and live animal export firms in particular and improve the existing marketing linkages with livestock traders that drive to achieve functional excellence and integration across all major business processes.

$>$ The study revealed the all live animal supply chain participants were used traditional way of gathering marketing information of personal observation. Awareness creation interventions should be conducted by concerned government bodies to increase the mutual relationships between livestock producer and their chain partners as well as to keep constant marketing practices among the supply actors.

$>$ The major challenges in live animal producers of the study area are quantity dispute, competition from illegal traders, insecurity of trade channel in supply chain, skill and knowledge of producers, standard government policy, and lack of supporting technology, local tax and disease in the export supply chain were faced should be overcome by implementing legal measure formulated from government bodies.

$>$ The major challenges in the live animal export supply chain of the study areas and the region in general are, such as lack of access to market information, lack of business support service provisions by concerned government institutions, lack of technology, insecurity of the routes, quality disputes and quantity disputes were faced by chain actors should be avoided by creating conducive administrative measure with all chain participants trends and concerned government bodies engaged in the sector in general.

$>$ Serious awareness creation workshops on livestock production, marketing and export regulation, policies and strategies have to be conducted for the supply chain participants and stakeholders of the

$>$ sector that aimed to create conducive conditions for export trade.

\section{Reference}

Agami, N., Saleh, M., \& Rasmy, M. (2012). Supply Chain Performance Measurement Approaches: Review and Classification. Journal of Organizational Management Studies Vol. 2, No. 20, pages 1-5.

AGP-LMD (2013). Agricultural Growth Project - Livestock Market Development (AGP-LMD):Value Chain Analysis for Ethiopia.

Album, M. and Griffth A. (2005). Mapping the market." a framework for rural enterprise development policy and practice. Practical Action: Markets and Livelihood Program.

Alemayehu K., and Ayalew T., (2012)Meat and Live Animal Export in Ethiopia: Status, Challenges and Opportunities. Global Advanced Research Journal of Food Science and Technology Vol. 2(4), pp. 054-059.

Alemayehu K. and Getu A. (2015). Beef Cattle Marketing and Illegal Trading in North Western Amhara, Ethiopia; Dynamic Journal of Animal Science and Technology Vol. 1(2), pp.43-48.

Aklilu, Y., \& Catley, A. (2010). Livestock Export from the Horn of Africa: An Analysis of Benefits by Pastoralist Wealth Groups and Policy Implications. Boston:Feinstein International Center, Tufts University.

Amha, S., Alemu, Y., Merkel, R. C., \& Gipson, T. A. (2011). Export requirements for meat and live small ruminants: How can development agents assist producers to improve small ruminant export? Addis Ababa:Ethiopia Sheep and Goat Productivity Improvement Program (ESGPIP).

Arend Jan Nell (2006). Quick scan of the livestock and meat sector. Ethiopia: Issues and opportunities.

Asegede M., Bsrat A., Hagos Y. and Gugsa G., (2015).Livestock Market Value Chain Assessment in Selected Sites of Tigray, North Ethiopia:Challenges and Opportunities for Enhancing Animal Product Export. Global Veterinaria 14 (1): 48-55.

Asfaw,N., Riccardo, C., George, M., Mohammad, J., Samuel, O., Mohamed, H. and Amos, O. (2008). Towards Improving Livestock Export Marketing Support Services in the Somali Context. Survey Findings and Implications: International Livestock Research Institute. 
Ayele, S., Assegid,W., Jabbar, M., Ahmed, MM. and Belachew, H. (2003). Livestock marketing in Ethiopia: A review of structure, performance and development initiatives.

Belachew, H. and Jemberu, E. (2003). Challenges and opportunities of livestock trade in Ethiopia.

Bereda A., Yilma Z., Asefa Z. and Kassa F. (2016). Livestock and Livestock Products and By-Product Trade in Ethiopia; ISSN 2224-607X (Paper) ISSN 2225-0565 (Online) Vol.6, No.7, 2016.

Cresswell, J.W. (2003). Research Design, Quantitative and Mixed Approaches. (2 ${ }^{\text {nd }}$ ed.). London: Sage Publishing Inc.

CSA. (2009). Agricultural Sample Survey. Addis Ababa, Ethiopia: CSA.

CSA. (2013/14). Agricultural Sample Survey. Addis Ababa, Ethiopia: CSA.

Daniel, T. (2008). Beef Cattle Production System and Opportunities for Market Orientation in Borena Zone: Southern Ethiopia.

David A. Riggs, Sharon L. Robbins; The Executive's Guide to Supply Management Strategies: Building Supply Chain Thinking into All Business Processes (Contributor) / Published 1998.

David S.; Designing and Managing the Supply Chain: Concepts, Strategies and Case Studies, / Published 1999.

Deards, B., Leith, R., Misfsud, C., Murray, C., Martin, P., \& Geelson, T. (2014). Live export trade assessment. Commonwealth of Australia: ABARES report to client prepared for the Live Animal Exports Reform taskforce of the Department of Agriculture.

Elias, M., Berhanu,G., Hoekstra, D. and Jabbar, M. (2007). Analysis of the Ethio-Sudan cross-border cattle trade: The case of Amhara Regional State.

Espalana, R., Nel, L., Abao, B., \& Vasquez, M. (2007). Development in the Supply Chain of the Philippine Goat Industry.Philippine:An Assessment.

European Union. (2013). Research \& innovation for a sustainable livestock sector in Europe. Animal Task Force.

Gebremariam, S., Amare, S., Baker, D., \& Solomon, A. (2010), Diagnostic study of live cattle and beef production and marketing:Constraints and opportunities for enhancing the system. Addis Ababa, Ethiopia: International Livestock Research Institute.

Gebrezgabher G. and Tesfaye Y. (2015). Market chain analysis of live goats Asaita District. Afar Regional State, Ethiopia: Published by IIED, April 2015 IIED Country Report.

Getachew, L., Hailemariam, T., Alemu, D., \& Negassa, A. (2008), Live animal and meat export value chains for selected areas in Ethiopia: Constraints and opportunities for enhancing meat exports. Addis Abeba, Ethiopia: Ethiopia Sanitary \& Phytosanitary Standards And Livestock \& Meat Marketing Program (SPS-LMM).

Getachew, L., Hailemariam, T., Dawit, A. and Asfaw, N. (2008), Live animal and meat export value chains for selected areas in Ethiopia: Constraints and opportunities for enhancing meat exports.

Ghatebi, M., Ramezani, E., \& Shiraz, M. A. (2013). Impact of Supply Chain Management Practices on Competitive Advantage in Manufacturing Companies of Khuzestan. Interdisciplinary Journal Of Contemporary Research In Business, Volume 5, No. 6 , 269-274.

Halala H. (2015), Review of Beef Cattle Value Chain in Ethiopia. ISSN 2224-6096 (Paper) ISSN 2225-0581 (online). Vol.5, No.7. Wolaita Sodo University, Ethiopia: College of Agriculture.

Handfield, R. and Betchel, C. (2002), The role of trust and relationship structure in improving supply chain responsiveness. Industrial Marketing Management.

Handfied,R. (2002). Writing the Ideal paper for Jom: A New Editor's perspective , 20,pp1-18

Hangara, G. N., Teweldemedhin, M. Y., \& Groenewald, I. B. (2012), Assessment on the constraints of cattle supply chain management in Namibia: Case study of Omaheke communal farmers. African Journal of Agricultural Research Vol. 7(35), pp. 4876-4884.

Irish, F.B. (2013/14), Export Performance and Prospects;Irish Food, Drink and Horticulture. Bord Bia. Irish Food Board.

Jei, F., Parton, K., \& Cox, R. (2007), Supply Chain Practice, Supply Chain Performance Indicators and Competitive Advantage of Australian Beef Enterprises: A Conceptual Framework. Australian Agricultural and Resource Economics Society (AARES 51st Annual Conference) (pp. 1-17). Queenstown, New Zealand: Faculty of Rural Management University of Sydney.

Koul, L. (1996), Methodology of Educational Research. New Delhi; Vikas Publishing House Pvt. Ltd.

Koul, L. (2008), Methodology of Educational Research. (3 ${ }^{\text {rd }}$ ed.). New Delhi: Vikas Publishing Agency.

La Londe (1999), Quick Response: Managing the Supply Chain to Meet Consumer Demand, / Published 1999.

Leta, S., \& Mesele, F. (2014), Spatial analysis of cattle and shoat population in Ethiopia: growth trend, distribution and market access. SpringerPlus , 1-2.

McDermott, J., Rich, K., Gebremedhin, B., \& Burrow, H. (2014), Value Chains and Innovation. Nairobi, Kenya.

Mclend, A., \& Sutherland, A. (2012), Animal production systems and supply chains: their role in providing employment and livelihood security and some implications animal welfare. The IDL Group.

Nauman, A. (2014), Enhancing Livestock Sector Export Competitiveness. Islambad, Pakistan. 
Negassa et al., (2008), Towards Improving Livestock Export Marketing Support Services in the Somali Context: Survey Findings and Implications. International Livestock Research Institute.

Netherland's African Business Council. (2010), Livestock in Ethiopia and opportunity analyses for Dutch investment. Addis Ababa: NABC.

Northern Smallholder. (2012), Northern Smallholder Livestock Commercialization Project (RRP LAO 47300). Laos.

Quesada, H., Gazo, R., \& Sanchez, S. (2015), Retrieved January 5, 2015, from www.intechopen.com: Supply Chain Management: A Case Study in the US Pallet Industry.

Robert B. Handfield, Ernest L. Jr. Nichols Introduction to Supply Chain Management. Published 1998.

SPS-LMMP. (2010), Ethiopia's Export Performance Review. access Capital; Investing In Ethiopia.

Sara, P. (2010). Harnessing the potential of cross border activities to improve livelihood security in the Horn of Africa dry lands. Working across borders.

Sintayehu, G., Samuel, A., Derek, B., and Ayele, S. (2010), Diagnostic Study of Live Cattle and Beef Production and Marketing. Constraints and Opportunities for Enhancing the System.

Slone,R.E (2004), leading a supply Chain Turnaround. Harvard Business Review, October, PP. 114-121.

SPS-LMMP. (2011), Focus on Ethiopia's Meat and Live Animal Export. Trade Bulletin Issued No 4, April 2011 , 1-3. Memo.

Tilahun, H., \& Schmidt, E. (2012), Spatial Analysis of Livestock Production Patterns.

Uddin, M. N., Islam, N., \& Quaddus, M. (2011), Supply Chain Performance of the Australian Beef Industry: Comparing the industry structure, Inter-firm relationships and knowledge systems of Western Australia and Queensland. Government of Western Australia: Department of Agriculture and Food.

Waters, D. (2003), An Introduction to Supply Chain Management. Printed in Great Britain: by Ashford Colour Press Ltd, Gosport. 